Historic, Archive Document

Do not assume content reflects current scientific knowledge, policies, or practices. 




\section{CRAB APPLES.}

Stayman, Montreal, Laura,
3 to $4 \mathrm{ft}$., 25 cents each; $\$ 2.50$ per dozen; $\$ 20$ per 100
Florence,
Molasses,
Hyslop,

Transcendent, Alaska.

\section{PEACH TREES.}

3 to $4 \mathrm{ft}$., 8 cents each; $\$ 7$ per $100 ; \$ 60$ per 1,000

2 to $3 \mathrm{ft}$., 6 cents each; $\$ 5$ per 100; $\$ 40$ per 1,000

Mary (Mary Choice), Reeves, Belle, Elberta, Bequette Free, Bequette Cling, Oldmixon, Denton, Chairs, Crawford Late, Orange Smock, Heath Cling.

\section{PLUM.}

4 to $6 \mathrm{ft}$., 25 cents each; $\$ 2.50$ per dozen; $\$ 18$ per 100

3 to $4 \mathrm{ft}$., 20 cents each; $\$ 2.00$ per dozen; $\$ 15$ per 100

WILDGOOSE GROUP.

Wildgoose,

Milton,

Whitaker,

Smiley.

CHICKASAW GROUP.

Newman.

WAYLAND GROUP.

Reed,

Wayland,

Benson,

Aurora,

Moreman.

JAPANESE GROUP.

Red June,

Abundance,

Chabot.

HYBRID GROUP.

Six Weeks, Waugh,

Gonzales,

America.

MINER GROUP.

Surprise.

AMERICANA GROUP.

Hunt, Hanson, Oren, Col. Bryan, Golden Queen, Smith.

\section{PEARS---STANDARD.}

4 to $6 \mathrm{ft}$., 25 cents each; $\$ 20$ per 100

Koonce, Tyson, Clapp Favorite, Bartlett, Seckel, Lawrence, Anjou, Kieffer.

\section{CHERRY.}

4 to $6 \mathrm{ft} ., 25$ cents each; $\$ 20$ per 100

Early Richmond,

Large Montmorency,

Tartarian,

Graffion

\section{QUINCE.}

2 to $3 \mathrm{ft}$., 25 cents each; $\$ 2.50$ per dozen; $\$ 20$ per 100

Rea,

Missouri Mammoth,

Bentley,

Bourgeat.

\section{STRAWBERRIES.}

$\$ 1.00$ per 100 by mail; 50 cents per $100 ; \$ 3.00$ per 1,000 by Express.

Cameron Early,

Climax,

Ideal,

Tennessee,

Paul Jones,

O. I. C., Chipman,

Helen Davis,

Crimson Cluster,

Gandy.

\section{JUNEBERRY.}

1 to $2 \mathrm{ft}$., 15 cents each; $\$ 1.50$ per dozen; $\$ 10$ per 100 


\section{GOOSEBERRIES.}

Houghton. The best variety for commercial planting. More resistant to mildew and easiest to gather, and yields more per acre.

2 year, well-rooted. $\$ 1$ per dozen; $\$ 6$ per $100 ; \$ 60$ per 1000

\section{BLACKBERRIES.}

10 cents each; $\$ 1.00$ per dozen; $\$ 5$ per 100 ; good plants.

MinNeWASKI. Large berry, fine quality and productive.

\section{CURRANTS.}

Well-rooted, good plants. 15 cents each; $\$ 1.50$ per dozen; $\$ 10$ per 100

\section{PAW-PAW.}

A small-sized tree, with large, clean, healthy deep green leaves. Fruit two to four, or more, incheslong; greenish-yellow skin; flesh yellow, soft; very sweet and rich. 5 to $7 \mathrm{ft}$., 50 cents each; 2 to $4 \mathrm{ft}$., 25 cents each.

\section{RHUBARB.}

MYATt Linneus. The best variety for family use. Plants from divided stools. 15 cents each; $\$ 1.50$ per dozen.

\section{GRAPE VINES.}

Two-year well-rooted vines; 15 cents each; $\$ 1.50$ per dozen; $\$ 8$ per 100 . ConCORD. 10 cents each; $\$ 1.00$ per dozen; $\$ 5$ per 100 .

BLACK VARIETIES.

Moore

Ohio

Campbell

Worden

Eclipse

McPike
Concord

Eaton

Nectar

Brown

Stark Star

Carman
RED.

$\begin{array}{ll}\text { Ulster } & \text { Jefferson } \\ \text { Banner } & \text { Wyorning } \\ \text { Vergennes } & \text { Brighton } \\ \text { Delaware } & \\ \text { Berckmans } & \\ \text { Centennial } & \end{array}$

WHITE.

Geneva

Martha

Winchell

Niagara

Pocklington

Diamond

\section{NUT TREES.}

\section{WALNUTS.}

Sieboldi (Japan). Nut ovate in form; shell smooth; kernels easily extracted, and are excellent in quality. Tree rapid in growth, handsome, bears young and heavily. 4 to $5 \mathrm{ft}$., 25 cents each; $\$ 2.50$ per dozen. 2 to $3 \mathrm{ft}$., 20 cents each; $\$ 2$ per dozen.

CORDIFORMIS (Japan). Nut heart shaped; easily cracked. Tree similar in habit to the preceding. Same price.

MANDSHURICA (Japan). Nut similar to the Butternut in form and rough shell. Tree a rapid grower and very productive. $1 \frac{1}{2}$ to $2 \mathrm{ft}$., 25 cents each.

ButTernut (American White Walnut). 4 to $6 \mathrm{ft}$., 25 cents each; 2 to $4 \mathrm{ft}$., 20 cents each; $\$ 10$ per 100 .

AmERican Black Walnut. 4 to $6 \mathrm{ft}$., 25 cents each; 2 to $4 \mathrm{ft}$., 20 cents each.

\section{SHELLBARKS.}

20 cents each; $\$ 2$ per dozen; 8 to 12 inches.

Small two-year trees from selected seed of the following choice varieties, viz:

Roosevelt. Very large nut and a robust growing tree.

WAUGH. Large, fine every way.

NORTON. Large, good form, productive.

DENTON. Very large, fine form, good cleavage, fine quality.

BRYAN. Very large nut, tree vigorous and productive.

ARROWHEAD. Quite large, pointed, productive.

Copious. Large, good cleavage, heavy bearer.

SophIE. Medium size, thin shell, fine.

KNISELY. Very large, good form, cleavage, good quality and bearer. 


\section{CHINKAPIN.}

$1 \frac{1}{2}$ to $3 \mathrm{ft}$., grafted, 75 cents each.

RUsh HYBRID. Claimed to be a cross between the Chinkapin and Chestnut. Bears young and abundantly.

\section{CHESTNUTS.}

Grafted; 2 to $4 \mathrm{ft}$., 50 cents each; $\$ 5$ per dozen.

\section{EUROPEAN.}

JAPANESE.

PARAGON. The best of the Europeans.

Numbo.

RIDGELY.

BLACK.

MARTIN.

KERR.

5 to $7 \mathrm{ft}$., 75 cents each.

Denton. A cross between Paragon-European, and Kerr-Japanese. Extra fine, 2 to $3 \mathrm{ft}$., $\$ 1.00$ each.

\section{SHADE AND ORNAMENTAL TREES.}

Norway Maple. 6 to $8 \mathrm{ft}$., 35 cents each; 8 to $10 \mathrm{ft}$., 50 cents each; extra large, from $\$ 1.00$ to $\$ 1.50$ each.

SugAR MAPLE. 8 to $10 \mathrm{ft}$., 50 cents each; 10 to $12 \mathrm{ft}$., 75 cents each; extra size, $\$ 1.00$ each.

CORK-BARK MAPLE. 7 to $8 \mathrm{ft}$., $\$ 1.00$ each.

CuT-LeAF Maple. 8 to $10 \mathrm{ft}$., 75 cents each.

Silver or Soft MaPLe. 6 to $8 \mathrm{ft}$., 25 cents each; 8 to $10 \mathrm{ft}$., 40 cents each.

SYCAMORE. 8 to $10 \mathrm{ft}$., 50 cents each.

TUlip POPLAR. 8 to $10 \mathrm{ft}$., 75 cents each.

AMERICAN LINDEN. 7 to $10 \mathrm{ft}$., 50 cents each.

SCARLET Willow. 7 to $10 \mathrm{ft}$., 50 cents each; 5 to $7 \mathrm{ft}$., 25 cents each.

CURLED-LEAF WEEPING Willow. 7 to $10 \mathrm{ft}$., 50 cents each.

LAUREL-LEAF WILLOW. 5 to $6 \mathrm{ft}$., 30 cents each.

\section{Hardy Flowering Shrubbery, \&c.}

Buddleia. Pendulous racemes of purple flowers; pretty. August and September. 20 cents each.

Deutzia. Pride of Rochester. White, double, fine. 20 cents each.

Crenata, Flora Plena. Pinkish, double. Same price.

Exochorda. Grandifora. White, showy. Same price.

Forsythia. Fortunii. Yellow, blooms early, profuse. 20 cents.

Viridissima. Yellow, bush spreading. 20 cents.

Hydrangea. Arborescetrs. Very fine, blossoms early and profusely; quite showy. Well-rooted plants. 25 cents.

Hydrangea. Paniculata Grandiflora. White, late to bloom. 20 cents.

JAPAN QUINCE. Both red and white varieties. 20 cents.

LiLAC. Single white An old time favorite. 20 cents.

“ Madam Lemoine. Very double, white, fine. 25 cents.

“ Cerulea Sitperba. Purple, very pretty. 20 cents.

" Rothomagensis. Rose, very large clusters; a beauty. 25 cents.

“ Leon Simon Dark purple, very double, very fine. 25 cents.

“ Alphonse Lavallee Dark crimson, very double. 25 cents.

“ lean Bart. Rose, very double, pretty. 25 cents.

SPIREA. Thunbergi. White, blooms very early. 20 cents.

"Van Houtii. White, very floriferous, handsome. 20 cents.

Weigela. Groenewegeri. Bright red, handsome. 20 cents.

"Van Houtii. Light red or rose. 20 cents.

\section{PERENNIALS.}

Peonies. Pink, cream and white, double. 15 cents.

ERIAN'THUS RAVENNA (Elephant grass). Good plants. 15 cents.

Eulalia. Zehrina. Good plants. 15 cents. 